\title{
Use and knowledge of Cactaceae in Northeastern Brazil
}

\author{
Camilla Marques de Lucena ${ }^{1 * \dagger}$, Reinaldo Farias Paiva de Lucena ${ }^{1{ }^{*}{ }^{*}}$, Gabriela Maciel Costa', \\ Thamires Kelly Nunes Carvalho', Gyslaynne Gomes da Silva Costa', Rômulo Romeu da Nóbrega Alves², \\ Daniel Duarte Pereira ${ }^{3}$, João Everthon da Silva Ribeiro' ${ }^{1}$ Carlos Antônio Belarmino Alves ${ }^{4}$, \\ Zelma Glebya Maciel Quirino ${ }^{5}$ and Ernane Nogueira Nunes ${ }^{1}$
}

\begin{abstract}
Background: This study aimed to record the use, and knowledge that residents from São Francisco community (Paraiba, Brazil) have regarding the Cactaceae.

Methods: Semi-structured interviews were carried out with 118 informants; 50 men and 68 women. The cacti cited in this study were organised into use categories and use values were calculated. Differences in the values applied to species and use categories by men and women were compared via a G test (Williams).

Results: The nine species identified were: Cereus jamacaru DC., Melocactus bahiensis (Brtitton \& Rose) Luetzelb., Nopalea cochenillifera (L.) Salm-Dyck., Opuntia ficus indica (L.) Mill, Opuntia stricta (Haw.) Haw., Pilosocereus gounellei (F.A.C. Weber) Byles \& Rowley, Pilosocereus pachycladus F. Ritter, Tacinga inamoena (K. Schum) N.P. Taylor \& Stuppy, Tacinga palmadora (Britton \& Rose) N.P. Taylor \& Stuppy. In total, 1,129 use citations were recorded, divided into 11 categories. The use value categories with the highest scores were forage $(0.42)$, food $(0.30)$ and construction (building) (0.25). P. pachycladus showed the greatest use value, versatility and number of plant parts used.

Conclusion: The survey showed that the Cactaceae is extremely important for several uses and categories attributed to different species. Apart from contributing to the ethnobotanical knowledge of the Cactaceae, another important focus of this study was to reinforce the necessity for further studies that record the traditional knowledge about this plant family, which has been lost in younger generations.
\end{abstract}

Keywords: Cacti, Ethnobotany, Use value, Semi-arid

\section{Background}

Despite the most widespread image of the Caatinga as belonging to a poor region, it is one of the richest regions in Brazil, regarding plant species number when compared to other ecosystems. Additionally, the region hosts a large number of endemic vegetable species, especially among the Cactaceae family. Due to this endemic feature and the high degree of environmental degradation due to anthropogenic activities, the Environment Administration Government has recognized the Caatinga as an area that requires conservationist actions [1]. A list of the most

\footnotetext{
*Correspondence: camillamlucena@gmail.com; reinaldo@cca.ufpb.br ${ }^{\dagger}$ Equal contributors

'Departamento de Fitotecnia e Ciências Ambientais. Setor de Ecologia e Biodiversidade, Universidade Federal da Paraíba. Centro de Ciências Agrárias. Laboratório de Etnoecologia, Areia Postal Code: 58.397-000, Brasil Full list of author information is available at the end of the article
}

vulnerable species (Normative Instruction $\mathrm{N}^{\circ}$ 06/ 2008) includes 28 cacti, and especially notable in this list is the genus Melocactus, with five endangered species in Bahia state [2].

The prominence of cacti in the Caatinga is due to their morphological and physiological adaptations to low rainfall, a limiting factor for living in a semi-arid region. Among these adaptations are the juicy stem, which stores water during the drought season, short stature, and leaves that have evolved into spines, which avoid water loss by evaporation [3]. Cacti are characterized as xerophytic plants, juicy, often thorny, with mucilaginous and watery tissue, the stomata are protected to diminish the superficial perspiration and roots absorb the night dew [4]. Cacti have a photosynthetically active stem, of variable colour, shape and size, forming cladodes, which

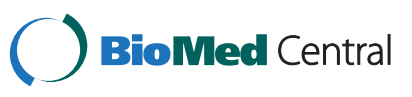


can be plain, cylindrical, columnar or globular and are usually coated with thorns. Regarding columnar cladodes, these have a central part, with a radial structure which forms from three to many angles [5-7].

The Cactaceae family is divided into four subfamilies: the Maihuenioideae, Pereskioideae, Cactoideae and Opuntioideae [8] that are spread throughout the American continent, in tropical and temperate regions, with the highest diversity of species occurring in Mexico. In Brazil, there are 40 genera and 200 species [9], of which 24 genera and 88 species are present in the Northeastern region [10]. These Northeastern species are differentiated from those of the South and Southeastern states, with Bahia state being the dispersion centre [11]. According to Barroso et al. [12], the difference between these two Brazilian groups is due the fact that the cacti from the northeastern region are similar to those species from North America, whereas those from the southern region maintain the characteristics of the South American species. Both groups are found in Brazilian semi-arid areas, such as Cereus jamacaru DC. (mandacaru), Pilosocereus gounellei (F.A.C. Weber) Byles \& G.D.Rowley (xiquexique), Melocactus bahiensis (Britton \& Rose) Werderm. (coroa de frade) and Pilosocereus pachycladus F. Ritter (facheiro) [13], as well as exotic species; e.g. Opuntia ficus indica (L.) Mill (palma forrageira) and Nopalea cochenilifera (L.) Salm-Dyck (palma doce).

According to Andrade et al. [14,15], apart from agriculturists who live in the northeastern semi-arid region and have a vast knowledge about the Cactaceae, few studies with an ethnobotanical focus have been performed to record the knowledge and diversity of uses applied to the species by the traditional population. In this sense, ethnobotany might considerably contribute to the recording of knowledge and use that agriculturists have about cacti and at the same time, provide information for the development and application of the sustainable handling of these plants. In other regions of the world, ethnobotanical studies on cacti are being initiated, e.g. in Mexico [16-22], Cuba [23], Colombia [24] and the United States [25], to analyse information concerning varied aspects of use, management and species domestication.

In Mexico, many species have been subjected to domestication due to the intensive use of fruit [18]. In Cuba, a medicinal use has been noted for several species [23] and in Colombia, one important use is that of fruit as human food [26] and also, in the United States, some species have a cultural value and are also used as childrens' toys [25].

One of the potential uses of cacti is as fodder species for cattle, sheep and goats during the drought season, together with native grass, with the aim of fattening the flock and increasing milk production $[4,26]$. Additionally, some industrialised products such as shampoo and soaps are produced mainly from the species $O$. ficus indica (forage cactus). Species such as $P$. gounellei (xiquexique), $P$. pachycladus (facheiro) and $M$. bahiensis (coroa de frade) are used to make biscuits, coconut candy, pudding, cakes and candies, and thereby provide a source of income for rural communities [14,27]. Cactus use in local medicine is also prevalent in rural communities in the treatment of illnesses such as infections, flu, urethra problems and worms [14] and use is also observed in home construction in many communities, as well as in the production of laths of P. pachycladus used in the building of roofs of houses $[26,28]$.

Further ethnobotanical studies are necessary, following the current trend of quantitative ethnobotany and economic botany, seeking to test hypotheses that relate to the knowledge and use of cacti, such as the hypotheses of ecological apparency [29,30], and optimal foraging $[31,32]$. What has determined the use and selection of these species? The selection is the choice of the species most preferred by people. Are there differences in knowledge and use by men and women? Are all the potential uses of cacti known, for both food and medicinal contexts? Have the species that have been used for medical purposes proven medicinal properties? Why are cacti so appreciated as ornamental plants? Has the spread of exotic cacti caused any ecological or other impact upon native species? All these questions might inform and direct future ethnobotanical research of this plant group. However, it was not used in this manuscript.

In view of the above and the utility shown by cacti, the present study aimed to record the knowledge and use by inhabitants of the São Francisco community in Cabaceiras city (Paraiba, Brazil), regarding the cacti found in the region.

\section{Materials and methods Study area}

The study was performed in the São Francisco rural community, in Cabaceiras city, Paraiba state (Northeastern Brazil) (Figure 1). This community is at approximately $400 \mathrm{~m}$ altitude and is located in the Meso-region from Borborema and micro-region from Eastern Cariri, $7^{\circ} 29^{\prime} 20^{\prime \prime} \mathrm{S}$ and $36^{\circ} 17^{\prime} 14$ 'W [33], situated $66.7 \mathrm{~km}$ from Campina Grande city (a regional hub) and $199 \mathrm{~km}$ from João Pessoa (the state capital). It has 5,035 inhabitants, 2,217 being in the urban zone and 2,818 in the rural zone, in an area of $452,920 \mathrm{~km}^{2}$ [34]. The climate is BSh (hot semi-arid), with a mean annual temperature exceeding $20^{\circ} \mathrm{C}$ and the lowest rainfall index in Brazil, with less than $300 \mathrm{~mm}$ of rain during the entire year [34]. The vegetation of the region is of the Caatinga hiperxerophilous type, being mostly characterised by the family Cactaceae and Bromeliaceae. 


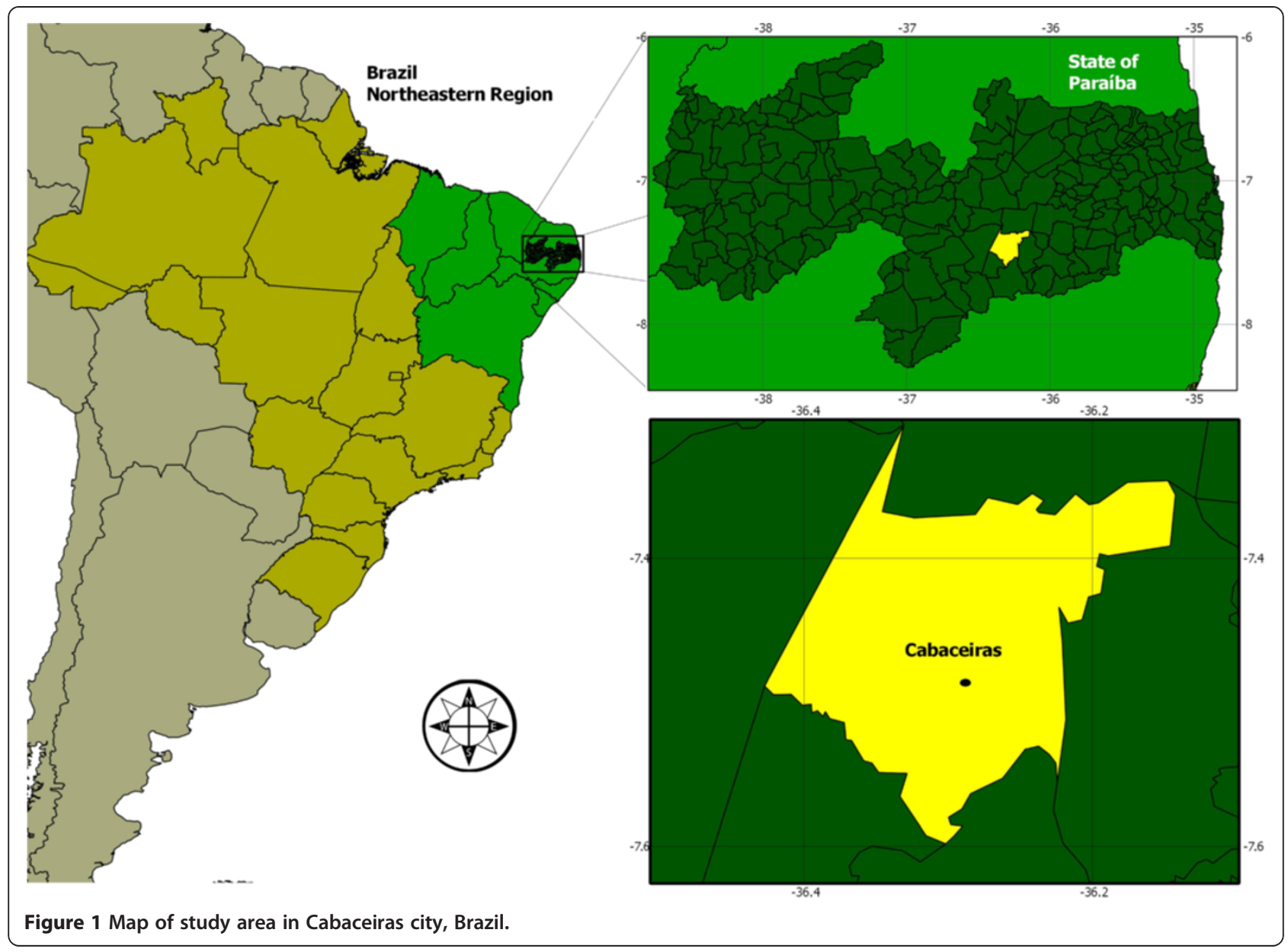

\section{São Francisco community}

The São Francisco community is divided into five localities called Caruatá de Dentro, Jerimum, Alto Fechado, Rio Direito and Malhada Comprida [35]. It has a basic education state school and a Catholic chapel located at Caruatá de Dentro, called São Francisco chapel. One of the main local economy sources is farming, including raising goats and maize and bean cultivation.

\section{Collection of ethnobotanical data}

Semi-structured interviews were performed with 118 informants (householders), in 72 homes, with both men $(\mathrm{n}=50)$ and women $(\mathrm{n}=68)$, in separate interviews [36]. The difference between the number of men and women occurred because of differing marital status', due to the presence of widows or widowers, single or divorced respondents. Each householder was considered as an informant. Before the start of each interview, each informant was explained the goal of this study and was requested to sign a Term of Free and Clarified Assent, demanded by the Health National Council through the Ethics and Research Committee (Resolution 196/96 of the CNS/MS). The study was developed and approved by the Committee of Ethics in Research with Human Beings (CEP) of the Lauro Wanderley Hospital from the Federal University from Paraiba, registered in protocol CEP/HULW no 297/11.

The community contained 88 habitable residences, which were all visited. Only in one residence did the residents decline to participate. For 15 other residences, the inhabitants could not be found, after being visited three times on average in an attempt to perform the interviews.

The form used to obtain the data involved questions referring to the knowledge of the informants about the use of the Cactaceae species found in the region: Which cacti do you know? Are any cacti used for building? Are any cacti used medicinally? Are there any cacti used for animal feeding? Who taught you? Do you teach anyone about cacti?

The cacti mentioned were organised into use categories adapted from the literature [14,37-40]. In each one of these categories (food, fuel, building, fodder plant, medicinal, ornamental, technology, veterinarian, shade, religious magic and personal hygiene), sub-categories were included, to indicate uses that were defined precisely 
and objectively, according to the course of the interviews. Collected field specimens were incorporated into the Herbarium Jaime Coêlho de Moraes (EAN) of the Federal University of Paraiba, at the Agrarian Sciences Center.

\section{Data analysis}

For each species and use category, the use value was calulated according to the formulae $\mathrm{VU}=\Sigma \mathrm{Ui} / \mathrm{n}$ and VUc $=\sum$ VUs/nc, described by Rossato et al. [41], where: $\mathrm{Ui}=$ number of uses mentioned for each informant, $\mathrm{n}=$ total number of informants, $\mathrm{VUc}=$ use value of each species in the category, VUs = use value of each species in the family, and $\mathrm{nc}=$ number of species in the category. When the use value of the species for men and women was calculated, the calculation was performed separately i.e., it was considered as the number of uses cited by all men, divided by the total number of men, the same procedure being adopted for women.
Differences in the values attributed to the species and the use categories for men and women were compared using the $\mathrm{G}$ test (Williams) [42].

\section{Results}

\section{Ethnobotanical inventory of the cactaceae}

Nine species, belonging to six genera were recorded: Cereus jamacaru DC. (mandacaru), Melocactus bahiensis (Britton \& Rose) Luetzelb. (coroa de frade), Nopalea cochenillifera L.Salm-Dyck. (palma doce) Opuntia. ficus indica (L.) Mill (palma forrageira), Opuntia stricta (Haw.) Haw. (palma de espinho), Pilosocereus gounellei (F.A.C. Weber) Byles \& Rowley (xiquexique), Pilosocereus pachycladus F. Ritter (facheiro), Tacinga inamoena (K. Schum) N.P. Taylor \& Stuppy (cumbeba), and Tacinga palmadora (Britton \& Rose) N.P. Taylor \& Stuppy (palmatória) (Figure 2). The number of different use citations was 1,129; 593 by women and 536 by men, which were organised into eleven use categories according to their utility.
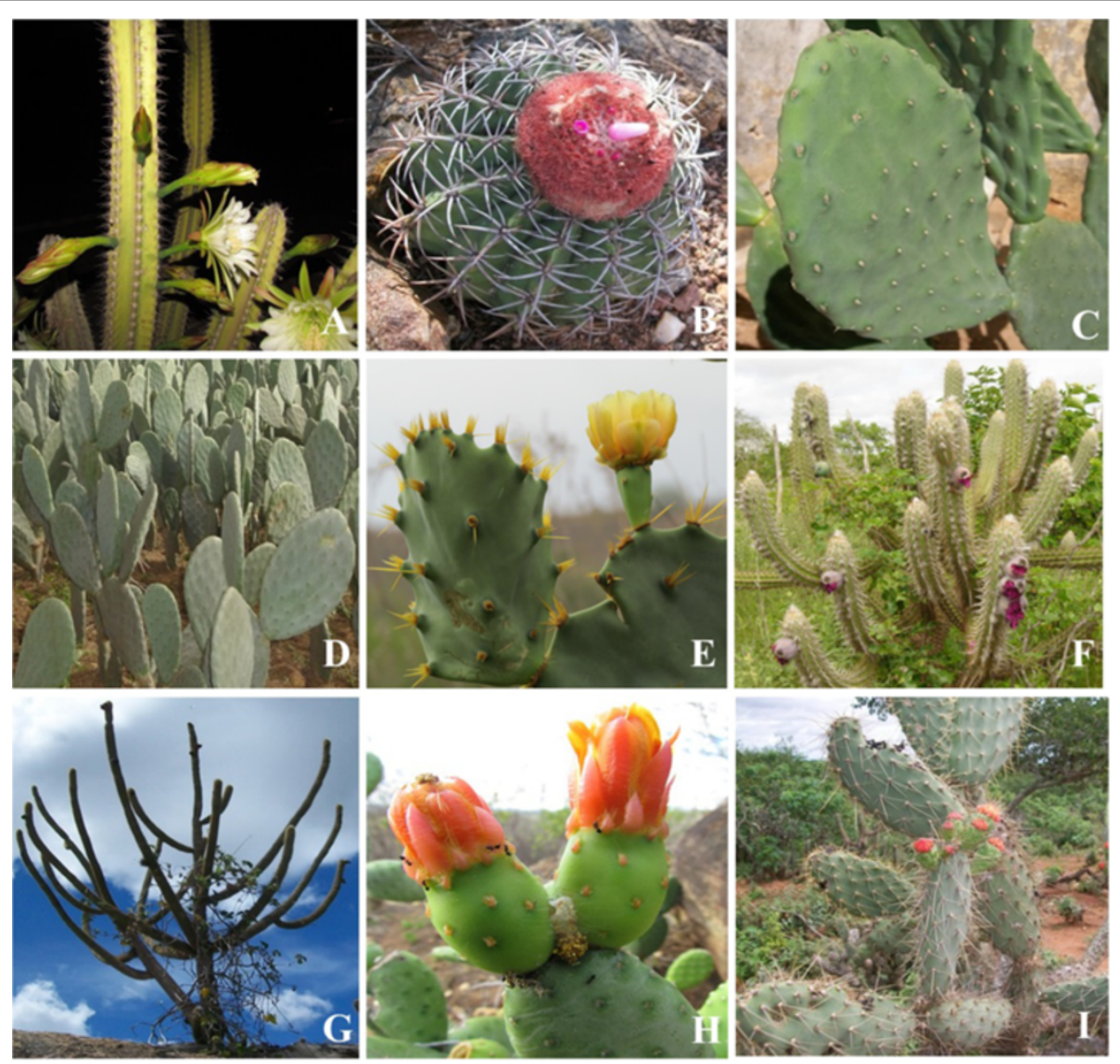

Figure 2 Cactus species cited by community residents of São Francisco in Cabaceiras city, Brazil. A. Cereus jamacaru DC.; B. Melocactus bahiensis (Britton \& Rose) Luetzelb.; C. Nopalea cochenillifera (L.) Salm-Dyck.; D. Opuntia. ficus indica (L.) Mill.; E. Opuntia stricta (Haw.) Haw.; F. Pilosocereus gounellei (F.A.C.Weber) Byles \& Rowley; G. Pilosocereus pachycladus F. Ritter; H. Tacinga inamoena (K. Schum.) N.P. Taylor \& Stuppy; I. Tacinga palmadora (Britton \& Rose) N.P. Taylor \& Stuppy. 
The most-mentioned species were $P$. pachycladus $(273$ citations), P. gounellei (227), O. ficus indica (210) and C. jamacaru (175), followed by M. bahiensis (126 citations), T. palmadora (84), T. inamoena (26), O. stricta (6) and $N$. cochilinifera (2). The use categories highlighted were: fodder, with 448 citations, representing $40 \%$ of the total, food with 293, building with 118, and ornamental with 61 (Figure 3). The use values of the above species, were P. pachycladus (2.31), P. gounellei (1,92), O. ficus indica (1.77), followed by C. jamacaru (1.48), Melocactus sp. (1.06), T. palmadora (0.71), T. inamoena (0.22), O. stricta (0.05) and $N$. cochenillifera (0.01).

Forage was the category with the highest use value (0.42), followed by food (0.30), building (0.25), ornamental (0.07), medicinal (0.10), technology (0.19), shade (0.10), fuel (0.15), religious magic $(0.02)$, personal hygiene (0.03) and veterinarian (0.008).

Regarding versatility, $P$. pachycladus and C. jamacaru fitted into eight of the eleven use categories, $P$. gounellei into seven, O. ficus indica into six, M. bahiensis into five, $O$. stricta into four, $T$. palmadora into three, $N$. cochenillifera into two and T. inamoena into one.

Analysis of the use of the different plants parts of individual species, showed that $P$. pachycladus and $C$. jamacaru had five useful parts, $O$. ficus indica and $P$. gounellei four, M. bahiensis and T. palmadora three, $O$. stricta, $N$. cochenillifera and $T$. inamoena two. The most-used part was the "entire individual" present in 474 citations and this use represents the cutting of the whole plant for subsequent burning and feeding to animals. After that, the wood received 178 citations, fruit 152, marrow (torch) 108, pulp (marrow) and rackets (cladode) 97, root with 11 and the gum (parenchyma) with six citations.
Amongst the seven native species recorded, $P$. pachycladus had the highest number of citations for building use.

Amongst the exotic species recorded, O. ficus indica was most used as forage, its cut cladodes being used for animal feed.

\section{Use of the cactaceae}

In the studied community, various ways of using of cacti found in the region were recorded, involving uses such as for timber or non-timber. All informations of use are presented in Table 1. Below are described some usage information for each species.

Cereus jamacaru is used for cooked human food or as an ingredient in candies and its fruit is consumed fresh. Its wood is used in construction, for making doors, windows, boards and laths. As part of its medicinal use, it can be used as a tea, being prepared from the root and used to treat illnesses such as rheumatism, wounds, boils, urinary infections and kidney inflammation.

Pilosocereus pachycladus has its core (marrow) cooked or baked and is used as human food, for making candy including coconut candy, or its raw fruit is consumed. A further use for its wood is as firewood to light domestic stoves, and in the manufacture of laths, "door guards", fences, doors, gates and boards.

Opuntia ficus indica is used for several purposes, the main one being for forage. It is also used in local cuisine, for cakes, candies, juices, jellies, soups, salads, stews, risottos or cooked with rice, beans and meat. The fruit is considered one of the best among all the Cactaceae, being also commercialized as "figo da Índia".

In the case of P. gounellei, its core (marrow) can be consumed either baked or cooked, becoming candy or

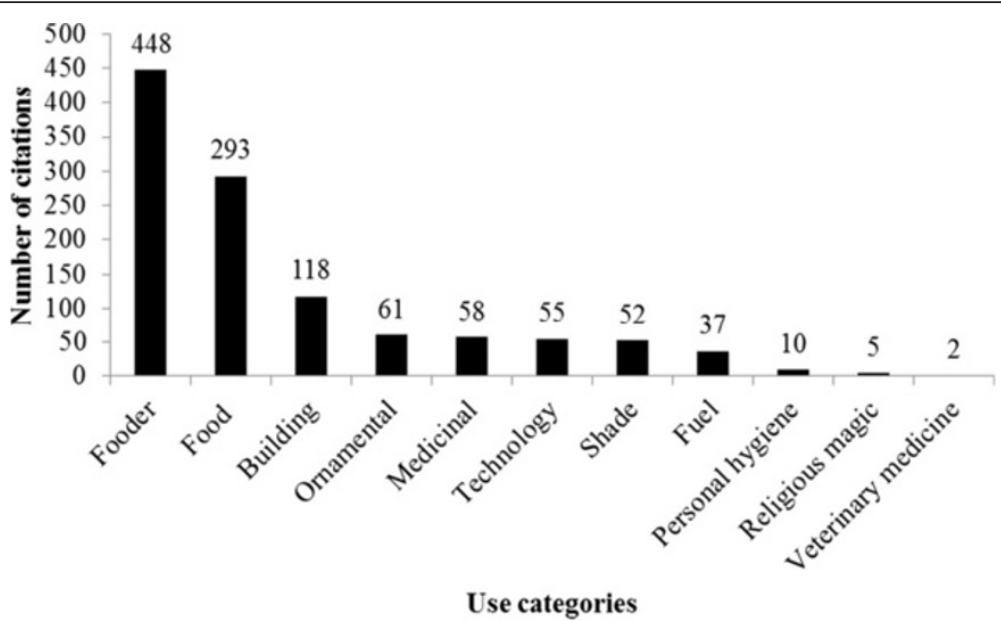

Figure 3 Number of citations of use by utilitarian category of cactus cited in the community of São Francisco in Cabaceiras city, Paraíba (Northeastern Brazil). 


\begin{tabular}{|c|c|c|c|c|c|c|}
\hline Species & $\begin{array}{l}\text { Vernacular } \\
\text { name }\end{array}$ & $\begin{array}{l}\text { Voucher } \\
\text { ufpb }\end{array}$ & $\begin{array}{l}\text { Categories of } \\
\text { use }\end{array}$ & Part used & Mode of use & Utilization \\
\hline \multirow[t]{9}{*}{ Cereus jamacaru DC. } & \multirow[t]{9}{*}{ Mandacaru } & \multirow[t]{9}{*}{17619} & Feeding & Fruit & In natura & \\
\hline & & & Fuel & Wood & Firewood & \\
\hline & & & Building & Wood & Laths, boards, doors and window & \\
\hline & & & Fodder plant & Entire plant & Burnt or cut & \\
\hline & & & \multirow[t]{2}{*}{ Medicinal } & Marrow & Syrups & $\begin{array}{l}\text { Cough, column, wound, furuncle, urinary infection, } \\
\text { inflammation, kidney inflammation, rheumatism } \\
\text { e urethra }\end{array}$ \\
\hline & & & & Root & Tea & \\
\hline & & & Ornamental & Entire plant & Planted in the gardens and yards & \\
\hline & & & Shade & Entire plant & & \\
\hline & & & Technology & Wood & Handle of tool & "Chibanca" \\
\hline \multirow{5}{*}{$\begin{array}{l}\text { Melocactus bahiensis (Britton \& } \\
\text { Rose) Luetzelb. }\end{array}$} & \multirow[t]{5}{*}{ Coroa de frade } & \multirow[t]{5}{*}{17572} & Feeding & Fruit & In natura & \\
\hline & & & Fodder plant & Entire plant & Burnt or cut & \\
\hline & & & \multirow{2}{*}{$\begin{array}{l}\text { Religious magic } \\
\text { Medicinal }\end{array}$} & Entire plant & Put into jars at home & Evil eye \\
\hline & & & & $\begin{array}{l}\text { Marrow (aquifer } \\
\text { parenchyma) }\end{array}$ & Syrups & Amoeba, catarrh, whooping cough, cough e worm \\
\hline & & & Ornamental & Entire plant & Planted in the gardens and yards & \\
\hline \multirow{2}{*}{$\begin{array}{l}\text { Nopalea cochenillifera (L.) } \\
\text { Salm-Dyck }\end{array}$} & \multirow[t]{2}{*}{ Palma doce } & \multirow[t]{2}{*}{19765} & Feeding & Fruit & In natura & \\
\hline & & & Fodder plant & Leaf (rackets) & Cut & \\
\hline \multirow[t]{7}{*}{ Opuntia ficus indica (L.) Mill. } & \multirow[t]{7}{*}{ Palma forrageira } & \multirow[t]{7}{*}{19769} & Feeding & Fruit & In natura & \\
\hline & & & & Marrow & Cooked or raw & $\begin{array}{l}\text { Cake, cooked with beans, with rice or with meat, } \\
\text { candy, stew, jelly, risotto, salads, soup and juice }\end{array}$ \\
\hline & & & Fodder plant & Leaf (rackets) & Cut & \\
\hline & & & Personal hygiene & Marrow & $\begin{array}{l}\text { Hair conditioner, soap, bath soap, } \\
\text { shampoo }\end{array}$ & \\
\hline & & & Religious magic & Entire plant & $\begin{array}{l}\text { Placing the leaf (racket) in the } \\
\text { bedroom of a sick person (asthma) }\end{array}$ & Asthma. Whooping cough and cough \\
\hline & & & Medicinal & Marrow & Syrups & \\
\hline & & & Shade & Entire plant & & \\
\hline \multirow[t]{4}{*}{ Opuntia stricta (Haw.) Haw. } & \multirow[t]{4}{*}{ Palma de espinho } & \multirow[t]{4}{*}{19764} & Feeding & Fruit & In natura & \\
\hline & & & Building & Entire plant & Hedges (fences) & \\
\hline & & & Fodder plant & Entire plant & Burnt & \\
\hline & & & Ornamental & Entire plant & Planted in the gardens and yards & \\
\hline
\end{tabular}


Table 1 Categories of use of cactus species cited by community residents of São Francisco in Cabaceiras city, Brazil (Continued)

\begin{tabular}{|c|c|c|c|c|c|c|}
\hline \multirow{8}{*}{$\begin{array}{l}\text { Pilosocereus gounellei } \\
\text { (F.A.C. Weber) Byles \& Rowley }\end{array}$} & \multirow[t]{8}{*}{ Xiquexique } & \multirow[t]{8}{*}{17629} & Feeding & Fruit & In natura & \multirow[t]{3}{*}{ Coconut candy, couscous, candy and flour } \\
\hline & & & & Marrow & Baked or cooked & \\
\hline & & & Building & Entire plant & Hedge & \\
\hline & & & Fodder plant & Entire plant & Burnt & \multirow[t]{2}{*}{ Remove the thorns from skin } \\
\hline & & & Personal hygiene & Marrow & Shampoo & \\
\hline & & & Medicinal & Dribble & Through the affected area & \multirow[t]{3}{*}{ Assist in the process of "not choke" } \\
\hline & & & Ornamental & Entire plant & Planted in the gardens and yards & \\
\hline & & & Veterinary medicine & Dribble & Insert dribble in the animal throat & \\
\hline \multirow[t]{13}{*}{ Pilosocereus pachycladus F. Ritter } & \multirow[t]{13}{*}{ Facheiro } & \multirow[t]{13}{*}{19616} & Feeding & Fruit & In natura & \multirow[t]{5}{*}{ Candy and coconut candy } \\
\hline & & & & Marrow & Baked or cooked & \\
\hline & & & Fuel & Wood & Firewood & \\
\hline & & & Building & Wood & $\begin{array}{l}\text { Fences, "door guard", door, gates, } \\
\text { laths, boards }\end{array}$ & \\
\hline & & & Fodder plant & Entire plant & Burnt or cut & \\
\hline & & & Medicinal & Entire plant & Cooked & \multirow[t]{3}{*}{ Anemia } \\
\hline & & & Ornamental & Entire plant & Planted in the gardens and yards & \\
\hline & & & Shade & Entire plant & & \\
\hline & & & \multirow[t]{5}{*}{ Technology } & \multirow[t]{5}{*}{ Wood } & Handle of tool & \multirow[t]{4}{*}{ Hoe, axes, hammers and pickaxe } \\
\hline & & & & & Roll of mass & \\
\hline & & & & & Canoe & \\
\hline & & & & & Oar & \\
\hline & & & & & Oil lamp (burning wood) & \multirow[t]{2}{*}{ Illuminate the nigth } \\
\hline \multirow{2}{*}{$\begin{array}{l}\text { Tacinga inamoena N.P. Taylor \& } \\
\text { Stuppy }\end{array}$} & \multirow[t]{2}{*}{ Cumbeba } & \multirow[t]{2}{*}{19766} & \multirow[t]{2}{*}{ Fodder plant } & Entire plant & Burnt or cut & \\
\hline & & & & Fruit & In natura & \multirow[t]{5}{*}{ Rhea } \\
\hline \multirow{4}{*}{$\begin{array}{l}\text { Tacinga palmadora (Britton \& } \\
\text { Rose) N.P. Taylor \& Stuppy }\end{array}$} & \multirow[t]{4}{*}{ Palmatória } & \multirow[t]{4}{*}{17573} & Feeding & Fruit & In natura & \\
\hline & & & Fodder plant & Entire plant & Burnt & \\
\hline & & & & Leaf (rackets) & Cut & \\
\hline & & & Ornamental & Entire plant & Planted in the gardens and yards & \\
\hline
\end{tabular}


flour for couscous preparation. The same plant part can be made into shampoo, or its raw fruit consumed. For fodder use, the entire plant is burnt and served to animals; alternatively, it can be used in gardens as an ornamental.

The types of uses recorded for Melocactus $s p$. include as fresh fruit for human food, the whole plant is burnt or cut for fodder or used as an ornamental or for religious magic uses (evil eye and envy) and the kernel (aquifer parenchyma) is used in the preparation of syrup used to combat whooping cough, phlegm and amoeba.

The fruit of $T$. palmadora is used as a human food; it can also be used solely as an ornamental, or also burnt and/or cut to feed animals.

Opuntia stricta is used in the composition of hedges (fences), and its fruit serves as human food. It is also burnt and used to feed animals, and used as an ornamental in gardens and yards.

The fruit of $N$. cochenillifera serves as a food for humans, and as fodder (rackets).

Tacinga inamoena is only used as fodder, being burned or cut down and offered to animals, or fed as a fresh fruit.

\section{Evaluation of species by men and women}

A comparison of the information provided by men and women showed that the most significant categories of fodder, feeding and building were the same for both groups. When analyzed using the $G$ test, the number of citations attributed to the species and the categories of use for men and women (Test $G(P)=0.1343$ ), didn't differ significantly, indicating that men and women tended to categorize the species in a similar way.

\section{Discussion}

\section{Use of the cactaceae}

The diversity of species and their uses registered in the present study were also noted in other studies, both in Brazil [14,15,43-45] and in other countries, such as Cuba [23]. Amongst these uses were those involving fodder and human food. However, the Cuban study diverged regarding the main recognized categories in the present study. In the Cuban community, the most obvious categories were medicinal and ornamental, with food being in third position, which unified uses for humans and animals [23]. However, a more detailed analysis is necessary in this context, because the category food is relevant in Cabaceiras as the use of cacti for food plays an important role in the cultural mentality of people from semiarid areas, even if using cacti for food is becoming less important, due to the fact that the local population is undergoing a social economic change as a result of governmental assistance, e.g., scholarships and family grants [35], suggesting an improvement in family income.
The use of cacti as a fodder plant is common, mainly during times of water shortage, when other forage species, such as those of the Poaceae family, are scarce, and cacti assume the main role in feeding the local flocks. As well as in the present study, the use of these plants as fodder plants mainly during drought periods, has also been noted by other researchers in Brazil [14,26,35,36,43,44,46]. Among fodder species, O. ficus indica, is predominant as a source of income, which stimulates its cultivation by agriculturists for their own use and/or for commercialization.

Medicinal and therapeutic uses were also well-recorded in the São Francisco community. The medical potential shown by cacti is mentioned in other studies, which demonstrate their various uses in the treatment of human illnesses [15,47-52]. In terms of veterinarian use, only a single species, $P$. gounellei was mentioned in this study. Andrade [53] reports that the same species is used medicinally by the "Sertanejos Baianos" people, being their "baba" mixed with castrated sheep mutton to remove stick tip off the skin.

Regarding the use of the cacti in domestic or rural constructions, the present study found considerable diverse uses, such as in the construction of roofs (laths), or to make gates. Such lumber uses are also noted in other semi-arid regions, as in Ceará [43], Bahia [14] and Paraiba [26]. A further lumber category that was registered in Cabaceiras was technology, for example, in the manufacture of handles of tools. However this use is little recognized in rural communities from semi-arid regions. Other uses recorded included the use of roots of P. pachycladus to make wooden spoons [43] and the hair (wooly trichomes) of $M$. bahiensis used in the wadding of the "cangalhas" (a type of saddle) for donkeys [44]. The prominence of certain species might result from their high use value, as the case of $P$. pachycladus, which was one of the most-cited species with great potential use by informants. Other researchers recorded uses for this species, thus confirming the findings in Cabaceiras, by Albuquerque et al. [36], who showed the culinary use (candy) in the Agreste from Pernambuco; Braga [43] highlights technological uses (wooden spoons made with the root), construction (boards), fodder plants and human food (fruit); and Gomes [46] describes forage uses.

P. gounellei demonstrated similar nutritional uses to those of $P$. pachycladus, in the daily life of Sertanejos Baianos who mainly consume its fruit [14]. Apart from this utilitarian potential, in Cabaceiras, it was also recorded as being useful for building "hedges", that could also then be surrounded by barbed wire. In Cuba, other cactus species with a similar use were recorded, such as Cereus hexagonous, O. ficus indica and $N$. cochenillifera, being associated with wooden props and wire [23], underlining the potential of cacti in this type 
of rural construction. Other studies have also listed uses for P. gounellei, such as for fodder $[43,44,46,52]$, ornamental $[44,52]$ or medicinal use [15,52], findings that confirm the uses in the community studied here.

O. ficus indica, as well as being a fodder plant, also showed a great variety of nutritional uses, being used to make cakes, candies, juices, salads, soups, jellies, or being cooked with beans, meat and rice, as well as use of the fruit itself. This alimentary potential also was noted by Andrade et al. [14] in Bahia. Other interesting aspects of certain cacti are their use as bio-indicators of natural phenomena, such as the rainy season. If specific questions on such phenomena had been asked, other responses might have been elicited, however, only one informant cited the use of cacti as bio-indicators, as can be seen from this citation:

"When the facheiro blooms with a yellow flower it is a signal that is going to rain" (A.R.F. 29 years old).

The use of cacti as indicators has been recorded in other studies for C. jamacaru in Pernambuco [36], and in Paraiba for P. gounellei, O. ficus indica and for $C$. jamacaru in Sumé city [54] and Soledade [55].

\section{Evaluation of species by men and women}

On average, men attributed greater use values and use categories to species, than women, even though the attributed values strongly correlated. This might be explained by the fact that men are more used to handling cacti, as they mainly cite uses related to animal feeding (fodder plants) than any other purpose, as found in the present study. Women were more familiar with uses for nutrition and personal hygiene, e.g. the use of $O$. ficus indica to make shampoo and bath soap. In semiarid regions, there is a division of labour, with men being responsible for the cultivation of food and women for preparing it, as reported by Cavalcanti Filho [35]. This is shown by the following citations from informants:

\section{"My wife already made cooked palma forrageira; she already used shampoo, bath soap and cream" (M.A.F., 45 years old).}

\section{"The stem of the facheiro serves as a board if it is} thick, to make a boat and oars" (M.S., 45 years old).

When analysing this division of labour and knowledge between men and women, taking into consideration all locally-found vegetable species, the literature has shown that there is a tendency for men to be more familiar with lumber uses and the women with non-lumber uses [56-59]. This was also observed in Cabaceiras, where men mentioned many lumber uses for cacti, such as building roofs (laths) and for tool handles (e.g. hoes), and women mentioned many non-lumber uses, such as those in disease treatment. However, Lucena et al. [40], emphasises that the dynamics of knowledge and use of vegetable resources between men and women might vary from region to region and either be similar or distinct. Matavele and Habib [60] found a similar knowledge for men and women, mainly regarding the use of medicinal plants. This same situation was found in the present study, since men and women attributed the same values of use to the medicinal category. Figueredo et al. [61] showed that women have a distinct knowledge from that of men, principally regarding the use of medicinal plants. In the general context of the São Francisco community, it is noted that maintenance of the knowledge concerning the Cactaceae is very important for both men and women.

\section{Conclusions}

The population from the São Francisco community demonstrated that the Cactaceae is extremely important due the diverse uses and categories attributed to different species. Exotic species as Opuntia ficus indica are increasingly being used by agriculturists as a fodder plant, as a new source of income within the community, and enabling the conservation of native species, such as Pilosocereus gounellei and Pilosocereus pachycladus.

The very high correlation of the use value between men and women demonstrates an equal knowledge for both sexes. In view of the demonstrated importance of cacti in this semi-arid region and of the richness of information acquired in the present study, it is suggested that similar studies should be performed to monitor knowledge within other communities and to allow a comparison with this study, as well as to consider the increased use and handling of cacti possibly via plantations, or through asexual propagation that would recognize the importance of these species in drought periods.

\section{Competing interests}

The authors declare that they have no competing interets.

Authors' contributions

All authors read and approved the final manuscript.

\section{Author details}

'Departamento de Fitotecnia e Ciências Ambientais. Setor de Ecologia e Biodiversidade, Universidade Federal da Paraíba. Centro de Ciências Agrárias. Laboratório de Etnoecologia, Areia Postal Code: 58.397-000, Brasil.

${ }^{2}$ Departamento de Biologia, Universidade Estadual da Paraíba. Centro de Ciências Biológicas e da Saúde. Avenida das Baraúnas, 351. Campus Universitário. Bodocongó. Campina Grande, Paraíba Postal Code: 58.109-753, Brasil. ${ }^{3}$ Departamento de Fitotecnia e Ciências Ambientais, Universidade Federal da Paraíba. Centro de Ciências Agrárias. Setor de Tecnologia Ambiental, Areia Postal Code: 58.397-000, Brasil. ${ }^{4}$ Departamento de Geografia e História, Universidade Estadual da Paraíba. Centro de Humanidade. Rodovia PB 075, 2001. Zona Rural, Guarabira Postal Code: 58.200-000, Brasil.

${ }^{5}$ Departamento de Engenharia e Meio Ambiente, Universidade Federal da 
Paraíba. Centro de Ciências Aplicadas e Educação. Tv. Manoel Gonçalves I, Rio Tinto Postal Code: 58.297-970, Brasil.

Received: 29 February 2012 Accepted: 24 August 2013

Published: 28 August 2013

\section{References}

1. Giulietti AM, Du Bocage Neta AL, Castro AAJF, Gamarra-Rojas CFL, Sampaio EVSD, Virgínio JF, Queiroz LP, Figueiredo MA, Rodal MJN, Barbosa MRV Harley RM: Diagnóstico da vegetação nativa do bioma Caatinga. In Biodiversidade da Caatinga: áreas e ações prioritárias para a conservação. Edited by Silva JMC, Tabarelli M, Fonseca MT, Lins LV. Brasília: Ministério do Meio Ambiente; 2004:48-90. DF.

2. MMA (Ministério do Meio Ambiente): Instrução Normativa No 06 de 23 de Setembro de 2008. Brasília; 2008:52.

3. Duque JG: O Nordeste e as lavouras xerófilas. Fortaleza: Banco do Nordeste do Brasil 2004, 4:103.

4. Duque JG: O Nordeste e as lavouras xerófilas. Mossoró. Coleção Mossoroense 1980, 193(3):265.

5. Barroso GM, Peixoto AL, Costa CG, Ichaso CLF, Guimarães EF, Lima HC: Sistemática de angiospermas do Brasil. vol. 1. In Livros Técnicos e Científicos. Edited by de Janeiro R. S.A.; São Paulo: Ed. da Universidade de São Paulo; 1978:255p.

6. Madgwick W: Cacti and other succulents. Austin, Texas: Steck-Vaughn Library; 1991:44p

7. Cullmann W, Goetz E, Groener G: The encyclopedia of Cact. Portland, Oregon: Timber Press; 1987:340p.

8. Wallace RS: Molecular systematic study of the cactaceae: using chloroplast DNA variation to elucidate cactus phylogeny. Bradleya 1995, 13:1-12.

9. Souza VC, Lorenzi M: Botânica sistemática: guia ilustrado para identificação das famílias de angiospermas da flora brasileira, baseado em APG II. Novo Odessa, SP: Instituto Plantarum; 2005:640p.

10. Zappi D, Rocha EA, Taylor N: Cactaceae. In Chechlist das Plantas do Nordeste Brasileiro: Angiospermas e Gymnospermas. Edited by Barbosa MRV, Sothers C, Mayo S, Gamarra-Rojas GFL, Mesquita AC. Brasília: Ministério de Ciências e Tecnologia; 2006:156p

11. Castro JP: Número cromossômicos em espécies de Cactaceae ocorrentes no Nordeste do Brasil. Dissertação de mestrado (Mestrado em Agronomia). Areia: Universidade Federal da Paraíba - Centro de Ciências Agrárias; 2008:70p.

12. Barroso GM, Peixoto AL, Ichaso CLF, Guimarães EF, Costa CG: Sistemática de angiospermas do Brasil. Viçosa 2002, 2:309.

13. Cavalcanti NB, Resende GM: Efeito de diferentes substratos no desenvolvimento de mandacaru (Cereus jamacaru P. DC.), facheiro (Pilosocereus pachycladus RITTER), xiquexique (Pilosocereus gounelli (A, WEBWR EX K. SCHUM.) BLY. EX ROWL.) e coroa-de-frade (Melocactus bahiensis BRITTON \& ROSE). Revista Caatinga 2007, 20(1):28-35.

14. Andrade CTS, Marques JGW, Zappi DC: Utilização de cactáceas por sertanejos baianos. Tipos conexivos para definir categorias utilitárias. Sitientibus. Série Ciências Biológicas (Etnobiologia) 2006a, 6:3-12.

15. Andrade CTS, Marques JGW, Zappi DC: Utilização medicinal de cactáceas por sertanejos baianos. Revista Brasileira de Plantas Medicinais 2006b, 8(3):36-42. Botucatu.

16. del Luna-Morale C C, Aguirre RJR: Classificación tradicional, aprovechamiento y distribución ecológica de la pitaya mixteca emMéxico. Interciencia 2001, 26(1):18-24.

17. Cruz M, Casas A: Morphological variation and reproductive biology of polaskia chende (cactaceae) under domestication in Central Mexico. Journal Arid Environment 2002, 51:561-576.

18. Arellano E, Casas A: Morphological variation and domestication of escontria chiotilla (cactaceae) under silvicultural management in the tehuacán valley, Central Mexico. Generic Resources and Crop Evolution 2003, 50:439-453.

19. Carmona A, Casas A: Management, phenotypic patterns and domestication of Polaskia chichipe (Cactaceae) in the Tehuacán Valley, Central Mexico. Journal Arid Environment 2005, 60:115-132.

20. Nilsen LB, Dhillion SS, Camargo-Ricalde SL, Rendón-Aquilar B, Heun M: Tradicional knowledge and genetic diversity of Opuntia pilifera (Cactaceae) in the Tehuacán-Cuicatlán Valley, Mexico. Economic Botany 2005, 59(4):366-376.

21. Casas A, Cruse-Sanders J, Morales E, Otero-Arnaiz A, Valiente-Banuet A: Maintenance of phenotypic and genotypic diversity in managed populations of Stenocereus stellatus (Cactaceae) by indigenous peoples in Central Mexico. Biodiversity Conservation 2006, 15:879-898.

22. Jiménez-Sierra CL, Eguiarte LE: Candy barrel cactus (Echinocactus platyacantus Link \& Otto): a traditional plant resource in Mexico subject to uncontrolled extraction and browsing. Econ Bot 2010, 64(2):99-108.

23. Fuentes VR: Etnobotánica de Cactaceae em Cuba. In Memorias del Taller Conservación de cactus Cubanos. Cuba: Jardim Botánico Nacional, Universidad de La Habana; 2005:15-24.

24. Fernández-Alonso JL: Nueva especie colombiana de Browningia (Cactaceae, Cactoideae, Browningieae) potencialmente promisoria para el país. Revista de la Academia de Ciências Exactas, Físicas y Naturales 2006, 30(114):19-30

25. Jiménez-Sierra CL, Eguiarte LE: Candy barrel cactus (Echinocactus platyacantus Link \& Otto): a traditional plant resource in Mexico subject to uncontrolled extraction and browsing. Economic Botany 2010, 64(2):99-108.

26. Pereira DD: Mangas, malhadas e cercados: o semiárido que não se rende!. Campina Grande: Impressos Adilson; 2009:102.

27. Pedrosa TM: Arte popular de Alagoas: pesquisa e organização. Maceió: Grafitex; 2000

28. Lima JL: Plantas forrageiras das caatingas: usos e potencialidades. Petrolina: EMBRAPA; 1996

29. Phillips O, Gentry AH: The useful plants of tambopata, Peru: I. Statistical hypothesis tests with a new quantitative technique. Econ Bot 1993a, 47:15-32.

30. Phillips O, Gentry AH: The useful plants of tambopata, Peru: Il. Additional hypothesis testing in quantitative ethnobotany. Econ Bot 1993b, 47:33-43.

31. Sih A, Christensen B: Optimal diet theory: when does it work, and when and why does it fail? Anim Behav 2001, 61(2):379-390.

32. Pyke GH: "Optimal foraging theory: a critical review". Annu Rev Ecol Evol Syst 1984, 15:523-575.

33. Atlas Geográfico do Estado da Paraíba: Secretária da Educação. Governo do Estado da Paraíba.. João Pessoa, Brasil: Grafset; 1985:100.

34. IBGE: Instituto Brasileiro de Geografia e Estatística. [www.bge.gov.br] (13 may 11)

35. Cavalcanti Filho JRC: A água como elo de identidades sociais no semi-árido paraibano: estudo de caso, Cabaceiras. Centro Universitário de Araraquara: Dissertação de mestrado (Mestrado em Desenvolvimento Regional e Meio Ambiente); 2010:196p.

36. Albuquerque UP, Lucena RFP, Alencar NL: Métodos e técnicas para a coleta de dados. In Métodos e técnicas na pesquisa etnobotânica. Edited by Albuquerque UP, Lucena RFP, Cunha LVFC. Recife: Editora NUPEEA; 2010.

37. Albuquerque UP, Andrade LHC: Conhecimento botânico tradicional e conservação em uma área de Caatinga no Estado de Pernambuco, Nordeste do Brasil. Acta Botânica Brasílica 2002, 16:273-285.

38. Albuquerque UP, Andrade LHC: Uso de recursos vegetais da Caatinga: 0 caso do agreste do estado de Pernambuco (Nordeste do Brasil). Interciencia 2002, 27:336-345.

39. Lucena RFP, Albuquerque UP, Monteiro JM, Almeida CFCBR, Florentino ATN, Ferraz JSF: Useful plants of the semi-arid northeastern region of Brazil a look at their conservation and sustainable use. Environ Monit Assess 2007 125:281-290.

40. Lucena RFP, Araújo EL, Albuquerque UP: Does the use-value of woody plants of the Caatinga (Northeastern Brazil) explain their local availability. Econ Bot 2007, 61:347-361.

41. Rossato SC, Leitão-Filho HF, Begossi A: Ethnobotay of Caiçaras of the Atlantic Forest Coast (Brazil). Econ Bot 1999, 53:387-395.

42. Sokal RR, Rholf FG: Biometry. New York: Freeman and Company; 1995.

43. Braga R: Plantas do nordeste, especialmente do ceará. Mossoró 1976 3:540

44. Andrade-Lima D: Plantas das caatingas. Rio de Janeiro: Academia Brasileira de Ciências; 1989:243p

45. Nascimento VT, Lucena RFP, Maciel MIS, Albuquerque UP: Knowledge and Use of Wild Food Plants in Areas of Dry Seasonal Forests in Brazil. Ecol Food Nutr 2013, 52:317-343.

46. Gomes RP: Forragens fartas na seca. 2nd edition. São Paulo: Nobel; 1973:236p.

47. Dantas IC, Guimarães FR: Plantas Medicinais Comercializadas no Município de Campina Grande, PB. Revista de Biologia e Farmácia 2007, 1:1

48. Chaves TP, Dantas IC, Felismino DC, Dantas VS, Dantas GDS: Lambedor: um conhecimento popular em abordagem científica. Revista de Biologia e Farmácia 2008, 2:1. 
49. Dantas VS, Dantas IC, Chaves TP, Felismino DC, Silva H, Dantas GDS: Análise das garrafadas indicadas pelos raizeiros na cidade de campina grande PB. Revista de Biologia e Farmácia 2008, 3:1.

50. Oliveira FCS, Barros RFM, Moita Neto JM: Plantas medicinais utilizadas em comunidades rurais de Oeiras, semiárido piauiense. Revista Brasileira de Plantas Medicinais. Botucatu 2010, 12(3):282-301.

51. Roque AA, Rocha RM, Loiola MIB: Uso e diversidade de plantas medicinais da Caatinga na comunidade rural de Laginhas, município de Caicó, Rio Grande do Norte (Nordeste do Brasil). Revista Brasileira de Plantas Medicinais 2010, 12(1):31-42. Botucatu.

52. Lucena CM, Costa GM, Sousa RF, Carvalho TKN, Marreiros NA, Alves CAB, Pereira DD, Lucena RFP: Conhecimento local sobre cactáceas em comunidades rurais na mesorregião do sertão da Paraíba (Nordeste, Brasil). Biotemas 2012 2012, 25(3):279-289.

53. Andrade CTS: Um estudo etnobotânico da conexão Homem/Cactaceae no Semi-Árido baiano, Dissertação de mestrado (Mestrado em Botânica). Universidade Estadual de Feira de Santana: Feira de Santana; 2020:102.

54. Abrantes PM, Sousa RF, Lucena CM, Lucena RFP, Pereira DD: Aviso de chuva e de seca na memória do povo: $\mathrm{O}$ caso do cariri paraibano. Revista de Biologia e Farmácia 2011, 5(2):18-24.

55. Lucena RFP, Araújo HFP, Mourão JS, Albuquerque UP: A flor chegou, chuva avisou: meteorologia popular no semiárido paraibano, Atualidades em Etnobiologia e Etnoecologia. Recife: Editora NUPEEA; 2005:2-205.

56. Luoga EJ, Witkowski ETF, Balkwill K: Differential utilization and ethnobotany of trees in kitulanghalo forest reserve and surrounding communal lands, eastern Tanzania. Econ Bot 2000, 54:328-343.

57. Taita P: Use of woody plants by locals in mare aux hippopotames biosphere reserve in western Burkina Faso. Biodiversi Conserv 2003, 12:1205-1217

58. Lacuna-Richman C: Subsistence strategies of an indigenous minority in the Philippines: nonwood forest product use by Tagbanua of Narra Palawan. Econ Bot 2004, 58:266-285.

59. Lawrence A, Phillips OL, Reategui A, Lopes M, Rose S, Wood D, Farfan AJ: Local values for harvested forest plants in Madre de Dios, Peru: towards a more contextualised interpretation of quantitative ethnobotanical data. Biodiversity Conservation 2005, 14:45-79.

60. Matavele J, Habib M: Ethnobotany in Cabo Delgado, Mozambique: use of medicinal plants. Environmental, Development and Sustainnability 2000, 2:227-234.

61. Figueiredo GM, Leitão-Filho HF, Begossi A: Ethnobotany of Atlantic Forest coastal communities: diversity of plant uses in Gamboa (Itacuruçá Island, Brazil). Hum Ecol 1993, 21:419-430.

doi:10.1186/1746-4269-9-62

Cite this article as: de Lucena et al:: Use and knowledge of Cactaceae in Northeastern Brazil. Journal of Ethnobiology and Ethnomedicine 2013 9:62.

\section{Submit your next manuscript to BioMed Central and take full advantage of:}

- Convenient online submission

- Thorough peer review

- No space constraints or color figure charges

- Immediate publication on acceptance

- Inclusion in PubMed, CAS, Scopus and Google Scholar

- Research which is freely available for redistribution

Submit your manuscript at www.biomedcentral.com/submit
( Biomed Central 